\title{
COMPRESSION STRENGTH CONCRETE WITH POND ASH LATI BERAU
}

\author{
Tumingan $^{1, \mathrm{a}}$, Muhammad Wihardi Tjaronge ${ }^{2, \mathrm{~b}}$, Victor Sampebulu, ${ }^{3, \mathrm{c}}$ and Rudy Djamaluddin ${ }^{4, \mathrm{~d}}$ \\ ${ }^{1}$ Student, Civil Engineering Hasanuddin University, Makassar Indonesia and Lecture, Civil Engineering Politechnic State of Samarinda, \\ Samarinda Indonesia \\ ${ }^{2}$ Professor, Civil Engineering Hasanuddin University, Makassar Indonesia \\ ${ }^{3}$ Professor, Architect Engineering Hasanuddin University, Makassar Indonesia \\ ${ }^{4}$ Assistent Professor, Civil Engineering Hasanuddin University, Makassar Indonesia \\ atumingan@yahoo.co.id, btjaronge@yahoo.co.jp, ${ }^{c}$ vicsam_ars@yahoo.com, ${ }^{\mathrm{d}}$ rudy0011@yahoo.com
}

\begin{abstract}
Handling of coal burning waste of thermal power plant in Lati, Berau district, East Kalimantan province, which is recommended by the department of environmental impact management is to dispose the coal ash into pools flowed water so that coal ash did not fly and cause air pollution. As known that coal ash waste is included hazardous and toxic waste, therefore managing it carefully is a necessity. Sediment or heap of coal ash in the sedimentation pond that is flowing with water is called Pond Ash. This study is conducted by utilizing the pond ash as a replacement material in the concrete mix. The effect of the use of pond ash as partial replacement of sand, fine aggregate in the concrete mix, is studied using cylindrical specimen with a diameter of $100 \mathrm{~mm}$ and a height of $200 \mathrm{~mm}$. Specimens were made by taking the ratio of the percentage of pond ash of $0 \%, 5 \%, 10 \%, 15 \%$ and $20 \%$ of the mixture of concrete with the constant water cement ratio 0.49 which is based on the results of normal concrete mix design. The compressive strength test of concrete was conducted at ages 1, 3, 7, 14, 28 and 90 days. The test results of compressive strength of concrete obtained showed an increase in compressive strength in accordance with the addition of pond ash in the mix. The adding of pond ash in the mix affected the increasing in the compressive strength of concrete, and the optimum strength is obtained in the ratio of $17 \%$ pond ash, which increased to $26.08 \mathrm{MPa}$ from $25.05 \mathrm{MPa}$ for concrete with and without pond ash mixes respectively, or increased by $4.12 \%$. This increase is not significant and cannot be used as a reference, however, by the results of this study it can be concluded that the pond ash waste can be utilized for the manufacture of concrete as a partial replacement of sand.
\end{abstract}

Keywords: Compression strength, concrete, coal ash waste, pond ash.

\section{INTRODUCTION}

Concrete is one of the materials which is the most widely used in construction, therefore the development of the material continues to be done to obtain better quality of concrete. Moreover, concrete is still considered as the most economical, readily available, and easy to use for structural components. This is because the reinforced concrete has a high compressive strength andhighdurability, and it does not need additional treatment for standard applications and located in the normal environmental without aggressive exposures. The disadvantage of concrete is it has low tensile strength, so the reinforcement is needed for the purposes withstand tensile stresses [1].

The Steam Power (power plant) that has now been operating in East Kalimantan and use coal fuel such as: Lati power plant $(2 \times 7 \mathrm{MW})$ which has been operating since May 11, 2004 requires coal as much as 8000 tons / month [2]. In addition, there are Kariangau power plant $2 \times 100 \mathrm{MW}$ [3], $2 \times 7 \mathrm{MW}$ in Tanah Grogot and $2 \times 7 \mathrm{MW}$ in Tanjungbatu Tenggarong Seberang, consequently a total of 242 MW could help the Mahakam system steam power plant [2].

According to the technical report of PT. PLN (Persero), as a comparison the steam power plant of
Asam-Asam, Tanah Laut district produces 60 tons coal ash waste for every use of 4,400 tons of coal. Since the operation of $2 \times 7 \mathrm{MW}$ requires 8000 tons/month of coal [4], then to produce $242 \mathrm{MW}$ power plant requires coal materials as much as 140,000 tons/month of coal, as a result around 1,885 tons/month the coal ash will be generated. This amount is quite large, so it requires a management that does not cause environmental problems such as air pollution, water pollution and degradation of ecosystem quality.

Operation of steam power plant using coal material resulted in solid waste such as coal ash. Based on the form of granules the coal ash is classified to soft granulated such as dust and it's called coal dust/coal fly ash, it flies when hit by wind, the dimension is very small that equivalent to sieve \#200. It contains $\mathrm{SiO}_{2}$, $\mathrm{Al}_{2} \mathrm{O}_{3}, \mathrm{P}_{2} \mathrm{O}_{5}$, and $\mathrm{Fe}_{2} \mathrm{O}_{4}$. The silica content $\left(\mathrm{SiO}_{2}\right)$ is sufficient with a high \pm 70 percent [5], allowing the coal ash to qualify as a material that has properties of cement/pozzolan.

Other coal ash has coarse grained, it's called coal bottom ash, grains such as black sand to grayish-not shiny. Fly ash and bottom ash is a coal combustion waste, non plastic, non cohesion and granular.

The process of coal ash waste management plant in East Kalimantan, based on the recommendation of the Environment Agency (BLH) of East Kalimantan Province it is conducted by soaking the coal ash mix of 
fly ash and bottom ash stacked/disposed of in a large pool or beach. The main purpose of the pool in order to flush/soak/wash coal ash, so that does not fly. A mixture of fly ash and bottom ash in a pond termed the pond ash.

Considering these conditions, this study tried to find a solution by utilizing the pond ash as a replacement material for the manufacture of concrete. Based on the gradation, pond ash meets the requirements of fine aggregate zone 3 , it was attempted utilizing the pond as to replace partially the sand in the concrete mix materials.

The commonly main purpose of concrete mix design is to get a high compressive strength of concrete. Due to the compressive strength of concrete properties is the main requirement in the calculation in designing structures. The compressive strength is directly related to the ability of the material to support under the applied loads. Moreover the compressive strength of concrete is affected by the constituent material so that the quality control of these materials as well as composition in the concrete mix must be composed carefully in order to obtain concrete according to the desired strength.

Result of research about the using of coal ash waste (fly ash and/or bottom ash) as mixing in the concrete is among athers : Effect of coal bottom ash on the properties of concrete such as workability, bleeding, setting times, compressive strength, split tensile strength, flexural strength, shrinkage, and durability [6], Upgraded incinerator bottom ash can replace up to 20 $\%$ sand and/or gravel in reinforced concrete and up to $50 \%$ in plain concrete [7], It was observed that up to $30 \%$ replacement the results of compressive, flexural, split and water permeability test are approximately same as that of the controlled concrete [8], The strength development for various percentages (0-50\%) replacement of fine aggregates with bottom ash can easily be equated to the strength development of normal concrete at various ages [9], indicate significant improvement in the strength properties of plain concrete by the inclusion of fly ash as partial replacement of fine aggregate (sand), and can be effectively used in structural concrete [10].

The aim of this study is to determine the compressive strength of concrete with the concrete mix made from pond ash as a substitute for sand/fine aggregate. To make concrete in accordance with the planned quality, the concrete composition determined by an analysis of the concrete mix design is required. In Indonesia, the standard SNI 03-2834-2000 is used for concrete mix design that provides tables and curves for concrete and use a normal type of Portland cement, the tittle of this standard is Procedures of Mix Concrete Manufacturing Plan for Normal Concrete.

Due to Portland Cement is no longer produced in Indonesia except on special request. While in many production and on the market are Portland Pozzolan Cement and Portland Composite Cement which certainly has different characteristics with Ordinary
Portland Cement, consequently the Portland Composite Cement is used in this study.

\section{MATERIAL METHODS \\ AND \\ EXPERIMENT}

Materials. The material used for normal concrete mix consist of cement, water, fine aggregate and coarse aggregate. Portland Composite Cement of Tonasa South Sulawesi is used as the hydraulic cement binder. Water for concrete mix is taken from the laboratory of construction materials, Polytechnic State of Samarinda. The fine aggregate used is river sand originating from Palu, while the coarse aggregate such as crushed stone coming from Palu, Central Sulawesi.

Cement. As mentioned before, recently an Ordinary Portland Cement (OPC) is no longer produced in Indonesia except on special request, while most construction uses Portland Composite Cement (PCC) or Portland Pozzolan Cement (PPC). In this study Portland Composite Cement is used. Criteria cement used to refer to the technical specifications of the Portland composite cement that is used for general purpose of construction (SNI 15-7064-2004). Inorganic material in the PCC includes furnace slag, silicate compounds of pozolan, limestone, with a total content of inorganic materials is around $6 \%-35 \%$ of the mass of Portland Composite Cement. Additional requirements for chemical content of $\mathrm{SO}_{3}$ in Portland Composite Cement is a maximum $4.0 \%$.

Aggregates. Sand and crushed stone for construction materials in East Kalimantan is not originating from local products, instead they are imported from Palu district, Central Sulawesi, because the local sand and crushed stone do not meet the technical requirements. Consequently to reduce dependence on imports of concrete materials an utilizing coal ash waste produced from the local area such as Lati Berau is conducted in this research.

Aggregate is one of the concrete filler material, and the role of aggregate in the concrete is very important. The content of aggregates in the concrete is approximately $60 \%-75 \%$ of the volume of concrete. The aggregate influence on the properties of concrete, so the selection of aggregates is an important part in making the concrete mix.

Pond Ash. Utilizing of pond ash in concrete can reduce pond ash waste, conserve natural resources and reduce environmental impact on human health and living things. Because of many steam power plants in East Kalimantan operates coal, raw material and dispose of wastes as pond ash. Pond ash used for this study was taken from the power plant PT. Berau Coal in Lati Berau Regency, East Kalimantan.

Compressive Strength of Concrete. Compressive strength of concrete is the main parameter that must be known and can give a description of almost all the other mechanical properties of concrete. This is because the main characteristics of the concrete are very strong in resisting the compressive force, but it is very weak in tensile force. The tensile strength of concrete is ranging 
from $10 \%$ to $15 \%$ of the compressive strength of concrete. Furthermore, in reinforced concrete structures design, the concrete is assumed to only play a role in restraining the compressive force and did not contribute to withstand a tensile force.

Compressive strength of concrete is concrete ability to withstand the compressive force in each unit area of the surface of the concrete. It is also expressed by the magnitude of the load per square area that causes the concrete test specimens were failures when loaded with a certain compressive force, which is generated by the compression test machine. Concrete compressive strength is calculated according to SNI 1974-1990, with the following equation:

Compressive strength of concrete, $f^{,}{ }_{c}=\frac{P}{A}$

with: $f^{\prime} c=$ Compressive strength of concrete $(\mathrm{MPa})$, $\mathrm{P}=$ maximum compressive load $(\mathrm{N})$,

$\mathrm{A}=$ total surface area $(\mathrm{mm} 2)$

\section{RESULTS AND DISCUSSION}

\section{Cement}

The cement used in this study was a Portland Composite Cement (PCC) produced by Tonasa. In Indonesian standard, SNI 15-7064-2004 set the physical requirements of cement, including requirements concerning bonding time with a Vicat test defined as follows:

Table 1. Terms physics as listed below.

\begin{tabular}{llccc}
\hline No & \multicolumn{1}{c}{ Description } & Unit & Terms & Result \\
\hline 1 & Bonding time with & & & \\
& the vicat: & minute & 45 & 110 \\
& - beginning binding & minute & 375 & \\
& - final binding & & & \\
\hline
\end{tabular}

The PCC oxide component is shown in Table 2.

Table 2. The oxides component of PCC.

\begin{tabular}{lll}
\hline No & Oxide & $(\%)$ \\
\hline 1 & $\mathrm{SiO}_{2}$ (Silica) & 19.44 \\
2 & $\mathrm{Al}_{2} \mathrm{O}_{3}$ (Alumina) & 0.52 \\
3 & $\mathrm{Fe}_{2} \mathrm{O}_{3}$ (Iron) & 2.36 \\
4 & $\mathrm{CaO}$ (Lime) & 64.25 \\
5 & $\mathrm{MgO}$ (Magnesia) & 0.48 \\
6 & $\mathrm{SO}_{3}$ (Sulfuric anhydride) & 0.35 \\
\hline
\end{tabular}

\section{Aggregates}

The testing methods of density and water absorption of aggregate use Indonesian national standards, SNI 031969-1990 and SNI 03-1970-1990 for coarse aggregate and fine aggregate respectively. The technical specifications of aggregate refer to ASTM C 33-90 Standard specification for concrete mixed. The physical properties of sand and crushed stone are listed in Table 3. Based on the results of the analysis of the specific gravity and absorption testing of all the aggregates used in this study were obtained the following results.

Table 3. Physical properties of sand and stone crushed.

\begin{tabular}{clcc}
\hline No & Physical properties & Sand & Stone crused \\
\hline 1 & Unit weight $(\mathrm{kg} / 1)$ & 1,362 & 1,522 \\
2 & SSD Density & 2,547 & 2,718 \\
3 & Absorption (\%) & 1,40 & 0,80 \\
4 & Abrasion Los Angeles (\%) & --- & 16,6 \\
\hline
\end{tabular}

\section{Grading Aggregates}

The results of sieve analysis for fine aggregate, coarse aggregate and ash pond are plotted in the graph. According to specifications, obtained results for the gradation of sand is categorized as zone 1, while the pond ash in the category zone 3 , as shown in the Figure 1.
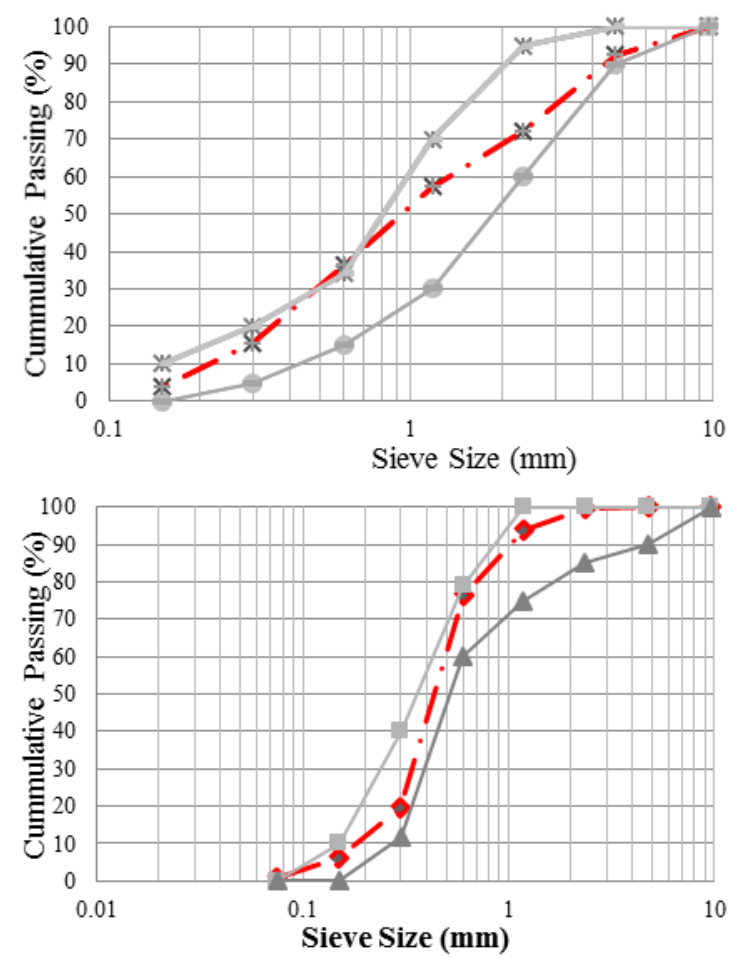

Figure 1. Gradation of sand categorized as zone 1 (left) and pond ash as zone 3 (right).

Based on the results of sieve analysis of the concrete mix consisting of sand, crushed stone and pond ash, the combined variations of materials is designed in accordance with the composition based on the specifications defined in SNI 03-2834-2000. Variation of mixed composition is initially calculated by the percentage of trial combined gradation between crushed stone and sand without adding the pond ash. Finally, the ratio of sand and crushed stone is obtained, that is $37.5 \%$ and $62.5 \%$. The combined results were plotted on a combined graph of aggregate gradation as shown in Figure 2.

The next composition variation is specified by the percentage of crushed stone $62.5 \%$, while the percentage of sand is reduced in accordance with the addition of pond ash. The total combined percentage of 
these three ingredients is still $100 \%$, the results are plotted in the combined gradation graph of three materials (sand, crushed stone and pond ash). The graph shows that all four of these variations meet the requirements of combined gradation with the maximum diameter of $20 \mathrm{~mm}$.

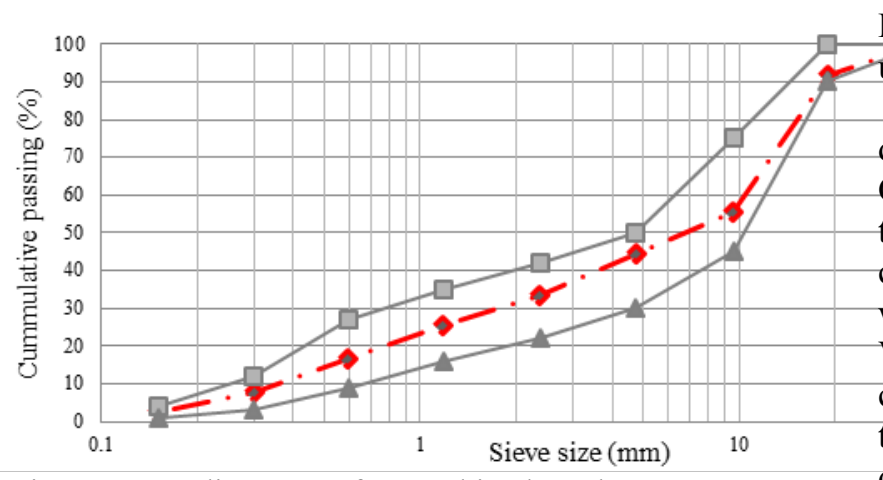

Figure 2. Grading curve for combined sand $37,5 \%$ : crushed stone $62,5 \%$.
Concrete designed using the effective compressive strength of $\mathrm{f}^{\prime} \mathrm{c}=25 \mathrm{MPa}$ with water cement ratio value is set at 0,49 corresponding concrete mix design based on SNI 03-2834-2000. The characteristics of each variation of concrete with five variations are provided in Table 4. Mixing concrete is conducted by the mixer. Prior mixing concrete the aggregates were prepared under Saturated Surface Dry (SSD) conditions.

Five variations of mixture composition are made to determine the compressive strength of concrete. Concrete samples are made from pond ash waste with the variation set at $0 \%, 5 \%, 10 \%, 15 \%$ and $20 \%$ of the combined aggregate weight and a normal concrete without a replacement pond ash as a control sample. Variations in pond ash content of $0 \%$ are the compressive strength control. For any kind of variation, the test spegimens of concrete are cylinders with a diameter of $100 \mathrm{~mm}$, a height of $200 \mathrm{~mm}$.

\section{Mix Design}

Table 4. Mix proportions.

\begin{tabular}{clcccccc}
\hline No. & Mixture & Unit & PA1 & PA2 & PA3 & PA4 & PA5 \\
\hline 1 & Cement & $\left(\mathrm{kg} / \mathrm{m}^{3}\right)$ & 404.08 & 404.08 & 404.08 & 404.08 & 404.08 \\
2 & Water & $(\mathrm{ltrs})$ & 200.88 & 240.96 & 281.03 & 321.10 & 361.18 \\
3 & Pond ash & $(\%)$ & 0.00 & 5.00 & 10.00 & 15.00 & 20.00 \\
4 & Pond ash & $\left(\mathrm{kg} / \mathrm{m}^{3}\right)$ & 0.00 & 48.84 & 97.69 & 146.53 & 195.37 \\
5 & Sand & $\left(\mathrm{kg} / \mathrm{m}^{3}\right)$ & 666.89 & 577.97 & 489.05 & 400.14 & 311.22 \\
6 & Stone Crushed & $\left(\mathrm{kg} / \mathrm{m}^{3}\right)$ & $1,128.15$ & $1,128.15$ & $1,128.15$ & $1,128.15$ & $1,128.15$ \\
7 & Concrete Density & $\left(\mathrm{kg} / \mathrm{m}^{3}\right)$ & $2,400.00$ & $2,400.00$ & $2,400.00$ & $2,400.00$ & $2,400.00$ \\
\hline
\end{tabular}

The moulded test specimen is left in the mold for 24 hours and then opened from the mold to be further treated. Treatment is done by soaking the specimen in water as long as the determined time for compressive strength testing of the age of $1,3,7,14,28$ and 90 days, with each variation consisted of two samples. The number of the total specimens made entirely with 5 variations of composition of pond ash as a material substitute for sand (fine aggregate) by 60 (sixty) pieces.

Information about generating compressive strength for the various age test, carried out an analysis to find the relationship between the various ages and resulted compressive strength. This is done on concrete made from a variety of pond ash percentage. In this analysis, the average value is obtained from the test of the specified object.

The development of compressive strength of each concrete made using pond ash as replacement of fine aggregate by hydration time is given in Figure 3.

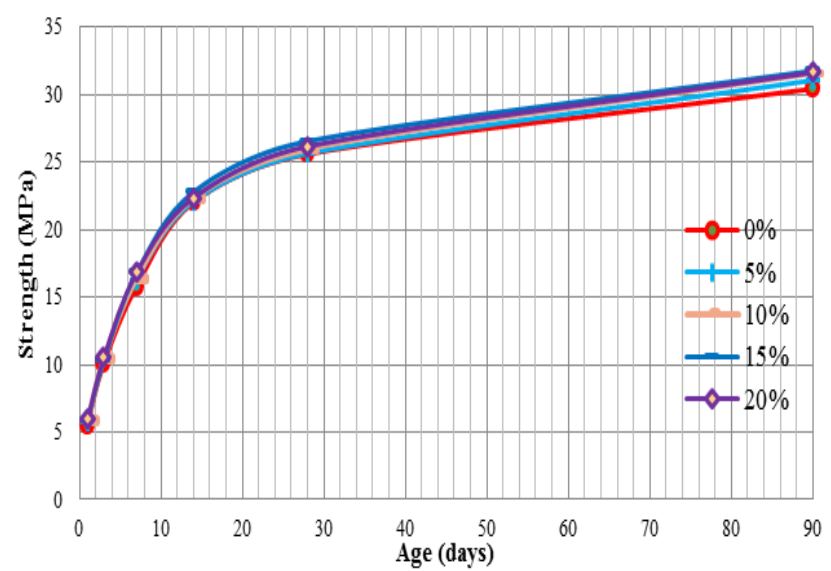

Figure 3. Graph of increasing in compressive strength.

Based on the Figure 3, it can be seen that the compressive strength, for all types of concrete, increased in accordance with the increasing in hydration age. Increased compressive strength of concrete appear faster on the initial hydration age, up to 28 days, and a further increase is likely to be slower and even the development of compressive strength began to stabilize with a small improvement. Concrete made using pond ash as replacement of fine aggregate develop a higher compressive strength when compared to normal concrete/control made without substitutes pond ash at the hydration age after 28 days. Before reaching the age 
of 28 days, concrete with increasing variety of fine aggregate replacement shows higher growth for a higher percentage of pond ash when compared to concrete with aggregate replacement fewer. However, by increasing hydration age the differences of compressive strength development have become increasingly apparent. A graph of compressive strength development is shown in Figure 4.

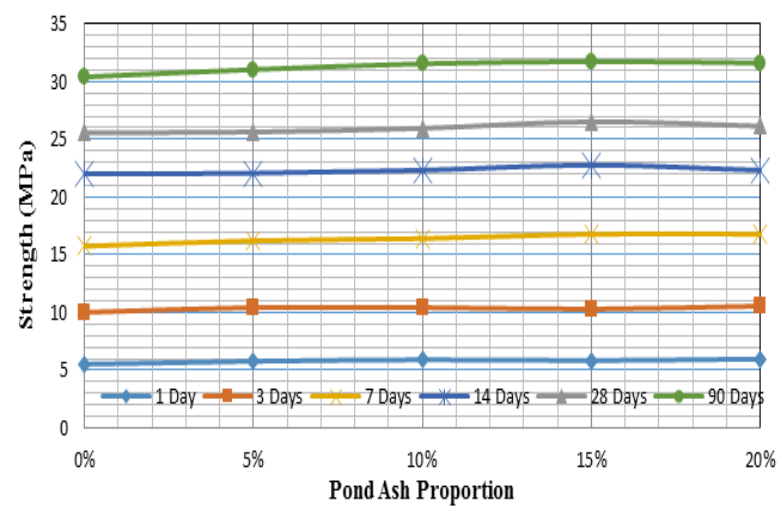

Figure 4. Graph of compressive strength development.

Figure 4 shows that the compressive strength of concrete is still the same at the age of 1 day of testing. At the age of 3 days test, the compressive strength test results indicate that the compressive strength decreases in proportion to the addition of pond ash in the mix, then constant up to the test at the age of 14 days. At the age of 28 days, the compressive strength increased until the age of 90 days.

Furthermore, based on Figure 3 the increase in the compressive strength of concrete for each variation of pond ash, compiled by calculating the compressive strength of the average of each composition variations in the materials used after conversion to compressive strength 28 days, unless the sample at the age of test 1 day. Produced compressive strength of concrete with variation pond ash as a substitute for sand, obtained a graph of the compressive strength of the concrete pond ash to variations in the levels of pond ash is used. The results are as shown in the graph, Figure 5 with an average compressive strength of the variations in the levels of pond ash of $25.53 \mathrm{MPa} ; 25.80 \mathrm{MPa} ; 26.10$ $\mathrm{MPa}$ and $26.03 \mathrm{MPa}$ when compared to normal/control with the average value of $25.05 \mathrm{MPa}$. As a result, by utilizing the pond ash in the concrete mix the comparison of compressive strength of concrete is found, which their strength higher than the normal concrete, that is $1.9 \% ; 3.0 \% ; 4.21 \%$ and $3.9 \%$ of the normal concrete respectively.

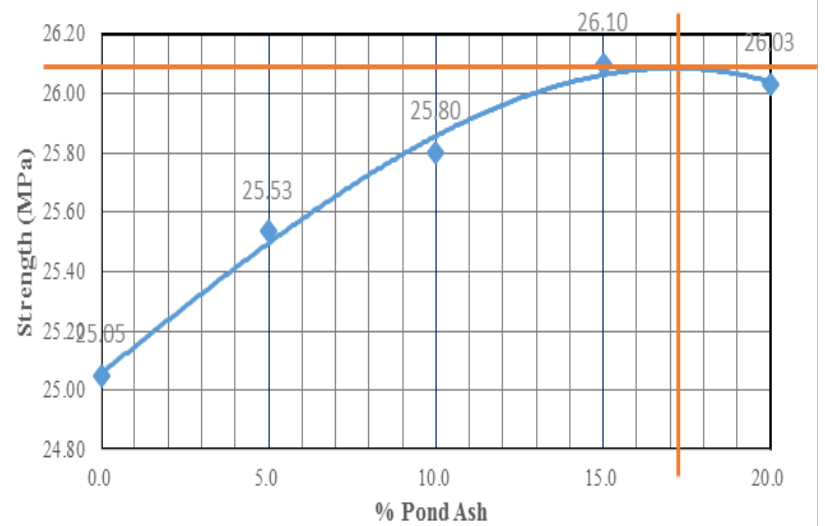

Figure 5. Graphs of optimum compressive strength.

Based on the analysis of optimum compressive strength of each composition and with the help of polynomial graphs, the optimum compressive strength is obtained in $26.08 \mathrm{MPa}$ or achieve an increase in the compressive strength of $4.12 \%$ of the compressive strength of normal/control concrete which has 25.05 $\mathrm{MPa}$, which occurred on the replacement of pond ash of $17.2 \%$.

\section{CONCLUSIONS RECOMMENDATIONS}

AND

Based on the description of analysis above, it can be argued that the use of pond ash from power plants in Lati Berau District of East Kalimantan as a substitute material for sand in sand ratio of $20.3 \%: 17.2 \%$ of pond ash: $62.5 \%$ of the crushed stone increased compressive strength of the concrete compared to the normal of $25.05 \mathrm{MPa}$ to $26,08 \mathrm{MPa}$ or an increase of $4.12 \%$. Because of the pond ash material is waste material that can be utilized and can reduce dependence on imports of sand, then the use of pond ash as a substitute of sand is still profitable economically and recycling of waste materials.

Further research can be conducted to determine the contained chemical composition in the concrete mix with pond ash as substitute materials to ensure the behavior of concrete compressive strength. Other tests also need to be carried out, such as tensile strength and the flexural strength.

\section{REFERENCES}

[1] Phil M Ferguson, Budianto Sutanto, Kris Setianto, Dasar-dasar Beton Bertulang, Edisi keempat, Erlangga, Jakarta, 1999.

[2] Information

on

http://bisnis.news.viva.co.id/news/read/138777-

pltu_200mw_dibangun_di_kalimantan_timur. Acces 16 May, 2015, 18:11.

[3] Information on http://diskominfo.kaltimprov.go.id/berita-pltu-teluk- 
balikpapan-ditarget-beroperasi-2015-html. (Sabtu, 26 Maret 2013). Acces 16 May 2015, 17:42.

[4] Information on http://ampost.co/berita/plnhadapi-kendala-tangani-limbah-abu-batubara, Acces 16 May 2015, 15:21.

[5] Tumingan, M. W Tjaronge, Rudy Djamaluddin and Victor Sampebulu, Compression Strength Of Concrete With Pond Ash As Replacement Of Fine Aggregate, ARPN Journal of Engineering and Applied Sciences, Vol. 9, No. 12, December 2014.

[6] Malkit Singh, Rafat Siddique, Effect of coal bottom ash as partial replacement of sand on properties of concrete, Resources, Conservation and Recycling 72 (2013) 20-32.

[7] Gert van der Wegen, Ulbert Hofstra, John Speerstra, Upgraded MSWI Bottom Ash as Aggregate in Concrete, Waste Biomass Valor DOI 10.1007/s12649-013-9255-6 Received: 18 October 2012 / Accepted: 10 June 2013.

[8] M.P.Kadam, DR.Y.D. Patil, Effect of Bottom Ash as sand replacement on the properties of concrete with different $\mathrm{W} / \mathrm{C}$ ratio, International Journal of Advanced Technology in Civil Engineering, ISSN: 2231-5721, Volume-2, Issue-1, 2013.

[9] P. Aggarwal, Y. Aggarwal, S.M. Gupta, Effect of Bottom Ash as Replacement of fine agregates in Concrete, Asian Journal of Civil Engineering (Building and Housing) VOL. 8, NO. 1 (2007) Pages 49-62.

[10] Rafat Siddique, Effect of fine aggregate replacement with Class $\mathrm{F}$ fly ash on the mechanical properties of concrete, Cement and Concrete Research 33 (2003) 539-547. 